\title{
WHEN NOT TO RESPECT
YOUR ELDERS
Tom Cliff
}

T MARCH 2017, a Uyghur cadre in Letian prefecture, south Xinjiang, was demoted and publicly reprimanded for failing to smoke in front of a Uyghur elder. The Global Times described the rationale thus:

According to local religion (sic) customs, smoking is not allowed in front of older people or among religious people... In a sense, whether officials 'dare to' smoke in front of religious people reflects their commitment to secularization. ${ }^{1}$

A commentator quoted in the Global Times claimed that it was an 'isolated case'. There was no suggestion that there is any official government order that prescribes smoking in certain situations. But similar reports have ap- peared over the past few years. Some village leaders have held beer-drinking competitions during Islamic religious festivals, for example, despite the prohibition on alcohol in Islam. Video from one such event showed middleaged Uyghur women competing to drink $600 \mathrm{ml}$ of beer the fastest. Across Xinjiang, authorities have reportedly forced pious Uyghur shopowners to sell both liquor and cigarettes. ${ }^{2}$

Such incidents represent attempts by low-level officials to demonstrate their 'anti-extremist' credentials. They apply what they understand to be the 'spirit' of instructions coming from above in ways calculated to win political points. This was surely the case in the demotion-for-not-smoking incident. Officials in Hetian would have been even more eager since early January, when the Xinjiang Commission 


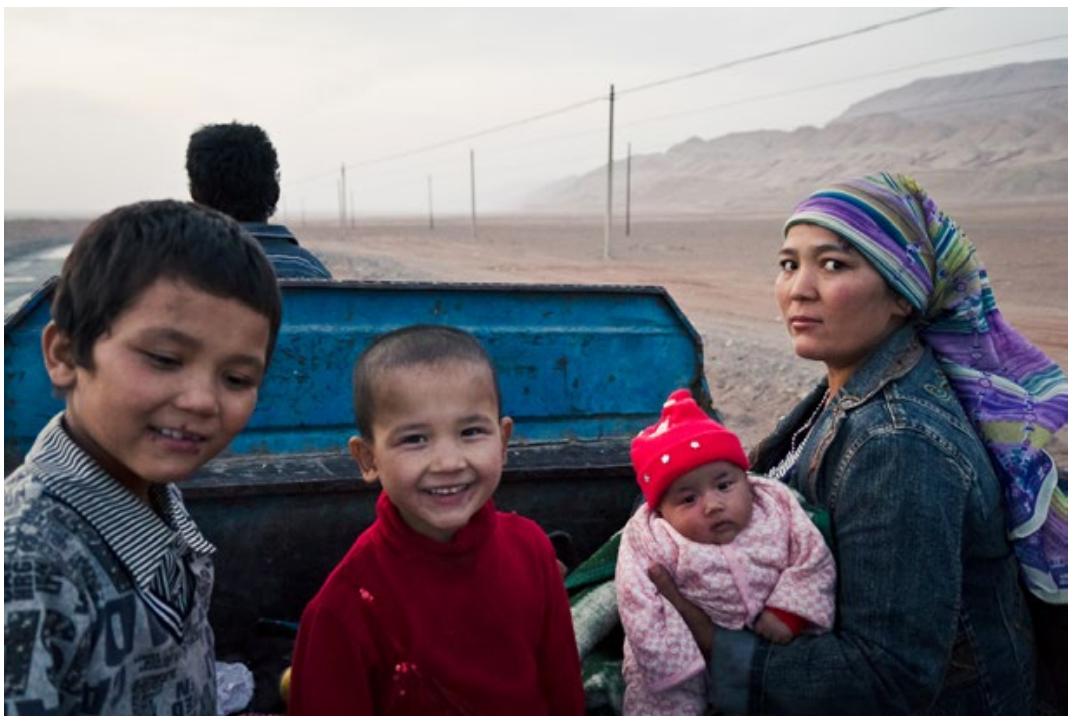

Uyghur family outside Tuyok village, Xinjiang Source: Damien Polegato, Flickr

for Discipline Inspection placed the prefectural Party Secretary, Zhang Jinbiao 张金彪, under investigation for 'serious disciplinary breaches' and 'dereliction of duty' following a fatal attack in December 2016 on a government building in the region. The Chinese authorities blamed Islamic separatists for the attack, in which five people died and three were injured. By early August, Zhang had lost his job and was declared guilty of 'violations of political discipline' and 'abnormal sexual relations', as well as 'not exert[ing] himself in carrying out his counter-terrorism and stability maintenance responsibilities'.
Fear drives official actions at all levels in cases like these. Fear of demotion or disciplinary action prompts local officials to scramble to demonstrate their own reliability and counter-terror efforts - in this case, by devising creative ways to carry out their superiors' absurd order to 'secularise religion'. ${ }^{3}$ Many recent incidents of violence have been sparked by the suppression of or disrespect towards Uyghur Islamic practices. Both producing and feeding off such incidents, many Han see the practice of Islam by Uyghurs as inherently threatening - and this fear is now institutionalised. 
One Saturday morning in summer 2009, I was crossing Construction Bridge in Korla, a Han-majority city in Uyghur-majority south Xinjiang. Also crossing the bridge were the well-off wives of Han Chinese oil company employees, families, peddlers, kids on skateboards, and six lanes of motorised traffic. Coming in the opposite direction was a large Uyghur group - a number of burqa-clad women, at least one bearded patriarch, younger men, and children. Suddenly, during a rare break in the traffic, the group of ten or twelve people left the footpath and headed diagonally across the road towards another, very similar, group that was crossing from the other side. The two groups met in the middle of the road and stood, exchanging handshakes, blessings, and lengthy salutations, as traffic ground to a halt. Some Han Chinese passers-by stopped and observed the spectacle. Nobody was vocally upset or abusive, but I could see that for many of them the actions of the Uyghur families were at once amusing and unsettling. Many Han people have used similar stories in discussions with me to demonstrate why they consider Uyghurs a 'backward' 落后 people.
The Uyghur groups' disregard for traffic rules were potentially unsettling to Han on a number of fronts. Han onlookers may feel that any attempt to move the Uyghurs on (by traffic police, for example) might cause offence and a conflict. Adding to the tension, the conservatively dressed Uyghurs were engaged in an exchange with visible religious overtones. Finally, by blocking traffic for this performance, the Uyghur families prioritised human relationships over regulations, and Islamic cultural etiquette over the modern ideal of continuous motion - so-called 'development'. This latter interpretation is borne out by observations in September 2017 that Chinese authorities were compelling shops and restaurants in Uyghur areas of Ürümqi to repeatedly play a 'somber acoustic tune that promotes core Communist values', and 'a jolly children's song about obeying traffic laws'. ${ }^{4}$ These two songs fulfil similar functions: stressing public order, productivity, and obedience.

The Uyghurs' actions thus posed a direct challenge to the social contract in Xinjiang. The social contract is based on the mutual interdependence of stability and development: Rising standards of living lead to greater so- 
cial stability, and social stability is deemed a necessary precondition for development. Moreover, to counter the 'Three Evil Forces' of terrorism, separatism, and extremism - and thus maintain stability - security forces must be granted extraordinary powers. Together, the theory goes, social stability and economic development will ensure the long and peaceful rule 长治久安 of the Chinese Communist Party. State discourse claims that Chinese occupation has brought development and modernity to Xinjiang, and liberated its people from feudalism, and promises it will be even better in the future. It says to non-Han: you are indebted to us and should be grateful. ${ }^{5}$

The two civilisations, Han and Uyghur, have aspects in common, for example, reverence for one's parents and elders, which the Chinese call 'filial piety'. But there are also differences, and these undermine some of the Party-state's efforts to 'modernise' Xinjiang. Ironically, ten years before the demotion-for-not-smoking incident, glossy booklets distributed to every household in Korla in 2007, as part of that year's spiritual civilisation campaign, stressed that it was uncivilised to smoke in confined public spaces and in the company of young children and women. Yet when carried out by a Uyghur in 2017, the civilised act of not smoking was instead connected first with Islam and thence with Islamic extremism, separatism, and terrorism, ultimately being construed as a threat to national security.

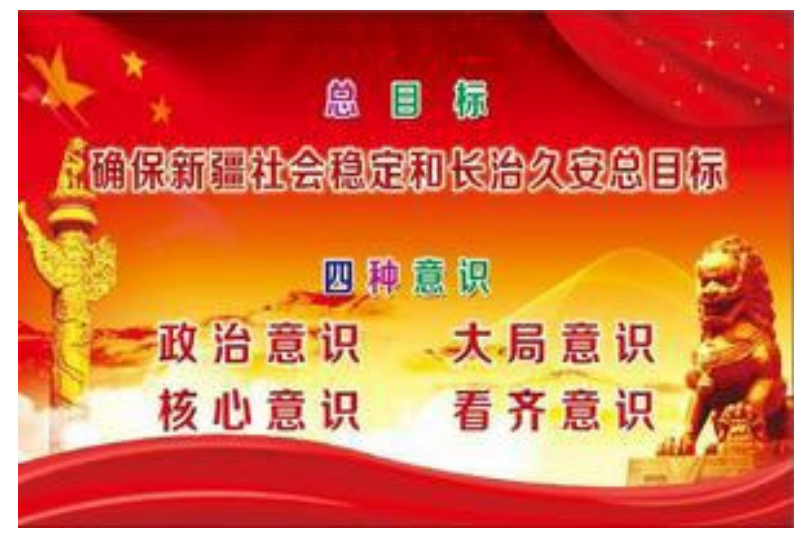

'Long and Peaceful Rule' propaganda

Source: 58pic.com 
This kind of thinking existed before the current Xinjiang Party Secretary Chen Quanguo 陈全国 took office in 2016, and it is an integral part of his approach to governing Xinjiang. 'All our work in Xinjiang,' he has declared, 'revolves around maintaining a tight grip on stability. ${ }^{6}$ Chen has since implemented a series of measures that are the most repressive and intrusive since Xinjiang was under the military rule of Wang Zhen 王震 in the early 1950s and arguably ever. The tactics of Wang Zhen and the Nationalist and Qing governors who came before him were brutal, but less comprehensive. In the interests of security, Chen has implemented grid-style surveillance, with small police observation stations no more than 500 metres apart in key urban areas. He tripled police recruitment in 2016 (adding 31,687 new positions), and then nearly doubled that again by August 2017 (over 53,000 new positions). Carrying on with programs begun under under his predecessor, Zhang Chunxian 张春贤, Chen has made it illegal to own a mobile phone that does not have a government surveillance app installed, and has greatly expanded the role of 're-education centres'. To become a candidate for incarceration and re-education, you may only need to possess banned religious materials (including most works published overseas), have accessed foreign Internet sites, studied or travelled overseas, dress in conservative religious garb, or be Uyghur, unemployed, and between fifteen and fifty-five years old. So many Uyghurs have been taken away without warning or explanation that some smaller communities' populations are noticeably depleted. Kazakhs in Xinjiang are now subject to the same pressures.

Things are not all rosy in Han Xinjiang either. Capital infrastructure construction continues to drive GDP growth. But many developers from other parts of China who came for the largely state-financed boom are nervous about the future, and are cutting their losses and heading back to eastern China. The Special Economic Zones and border trade zones that opened with much fanfare over the past five years are today nearly desolate. In late 2016, a few Han informants furtively warned me to be careful: 'Xinjiang looks all peaceful and beautiful, but underneath, it is bubbling with dissent and violence'. Both stability and prosperity appear increasingly elusive for both the Uyghur and Han populations in Xinjiang. 
This text is taken from China Story Yearbook 2017: Prosperity, edited by Jane Golley and Linda Jaivin, published 2018 by ANU Press, The Australian National University, Canberra, Australia.

doi.org/10.22459/CSY.04.2018.02A 